\title{
Using exercises to cope with the transference in the process of group counseling
}

\author{
Mehmet Boyac1 ${ }^{1}$
}

\begin{abstract}
People who have different characteristics maintain their life by communicating each other. Today people may have many problems related to their relationships with others. So they may need professional support when they could not find a solution for some personal or social problems which they have faced throughout their life. In this sense, Counseling and Group Counseling is a professional field having the aim of helping people to overcome those problems. Group counseling has some advantages compared to individual counseling. The feeling of not being alone within the group and transfer of the experiences learned in the sessions to social life are some advantages of group counseling. Besides its advantages, transference and countertransference may arise in group counseling process. In this article; the exercises which may help to the group leader to cope with transference and countertransference during the group counseling have been examined in a theoretical framework. Some exercises like role playing, empty chair and unfinished business were discussed in the light of literature. At the end of the study some recommendations and suggestions are offered to the counselors and the field professionals.
\end{abstract}

Keywords: Group Counseling; Transference; Countertransference; Psychological Health; Using Exercises; Counseling; Gestalt Therapy.

\section{Introduction}

Human as a social being maintains his life by establishing relationships with others around. Social troubles which people face arise as a result of these relationships (Duck, 2007:49). Hence, the relationships among people and way of communication directly affect their quality of life (Fehr, 2014). People may need professional support when they could not find a solution for some personal or social problems they have faced throughout their life (Gullo et al., 2015; Corey, 2012). In this context psychological counseling and group counseling is one of professional fields helping people to overcome these problems (Battle, 2016; Berg \& Landreth, 2013; Capuzzi \& Gross, 2014; Conyne, 2013; Hackney \& Cormier, 2008; Nazlı, 2014). Psychological counseling is a professional field came out to define much better interpersonal and personal problems (Capuzzi \& Gross, 2014). Psychological counseling studies on both the experiences in client's inner world and his relations with others (Hackney \& Cormier, 2008).

Counseling profession can be practiced as individual or in a group environment (Conyne, 2013; Nazl1, 2014; Vander Kolk, 1985). The main aim is to help that person both in individual

1Ph.D., Gazi University, Faculty of Education, Psychological Counseling and Guidance, mehmetboyaci1984@gmail.com 
counseling and group counseling (Nazlı, 2014). Group therapy has been used various areas like play therapy, depression, grief, suicidal groups, support groups, prevent prejudge, hypertension e.g. (Battle, 2016; Beelmann \& Heinemann, 2014; Goldblatt, Briggs \& Lindner, 2015; Nazarzadeh \& Foroutan, 2015; O'Rourke \& Worzbyt, 1996; Schaefer, 2011; Ulberg, Hersoug \& Høglend, 2012). Group counseling important because everyone should know the required behaviors and attitudes in relations to able to adapt to social environment (Fehr, 2014). These attitudes and behaviors helping to mend the interpersonal relations can be improved within small groups and then the person can transfer his experiences acquired in these groups to bigger ones, to his social environment in other words (Voltan-Acar, 2014). Group counseling may be defined as assistance groups focusing on the person's feelings, moral values and attitudes with the aim of improving interpersonal relations. As a result, people who have joined to group counseling learn to solve their problems which they have faced in interpersonal relations, and to meet their needs duly within these groups (Berg \& Landreth, 2013; Fehr, 2014).

Group counseling is an approach based on the learning model. In this model there is no patient; indeed people who have some compliance problems or the ones who want to have a different experience come to these sessions (Voltan-Acar, 2014). Persons who have joined to psychological group counseling learn new behaviors and then transfer them into social life. Both individual counseling and group counseling has a protective quality (Capuzzi \& Gross, 2014; Conyne, 2013; Nazl1, 2014). In other words, both individual counseling and group counseling are services having the aim of helping persons to solve their compliance problems. In this sense, group counseling is an effective method to solve the problems which people have faced throughout their life. Besides, transference and countertransference may arise in group counseling process. In this study, the norms of transference and countertransference which may arise in group counseling process were referred, and the methods of exercises to cope with transference have been explained.

\section{Transference and Countertransference in Group Counseling}

Transference and countertransference hindering the success of practices may arise during the group counseling (Marmarosh, 2012; Southern, 2007; Ulberg, Hersoug \& Høglend, 2012). The norm of transference is one of prominent contributions of Sigmund Freud in psychology (Freud, 1912). When Freud observed the studies of his colleague Joseph Breuer, he detected that his patient Bertha was attracted to Breuer. Bertha believed that she was pregnant with his baby although there was nothing between them beyond the doctor-patient relation. So Freud detected that patients were trying to establish a similar relation with their therapist just like the ones with important persons in their life. Freud defined this situation as transference. According to Freud, transference is an emotional process developed by the patient for the therapist (Freud, 1912). In treatment process, therapist may sometimes direct positive or negative feelings and reflections to the patient like in transference. Freud explained this situation as countertransference and thought that countertransference was an obstacle for an efficient therapy (Fehr, 2014).

In group counseling, participant form an interaction not only with the psychological counselor but also other members of the group. Thus, group counseling process includes more than one transference object (Voltan-Acar, 2014). According to Voltan-Acar (2014), transference in group counseling may be defined as a process in which one of the group members shares his feelings or unfinished business having affected him positively or negatively in the past with another member, the group leader or group. If a member within the group plays a role of a specific person in the life of another member, that person would be the transference object. Concisely, the process of transference consists of the member realized transference and the other having been the transference object. The group leader should understand both the feelings of the member realized transference and the other having been the transference object (Gullo et. al., 2015). 
Transference and counter transference should be studied to able to understand the dynamics of relation among the members and their emotional responses in group sessions (Fehr, 2014; Marmarosh, 2012; Southern, 2007). The group leader should understand the group dynamics, recognize transference and counter transference within the group to manage the process and know the methods to deal with them (Fehr, 2014). In this sense, the group leader should have the ability of individual psychological counseling to deal with transference and counter transference, and direct the whole process as well. In addition, some exercises may be benefited to cope with transference in group process providing that they are used at the right time with proper dose (Voltan-Acar, 2014).

\section{Exercises in Group Counseling Process}

In group counseling process group leader/counselor uses exercises and a game to obtain some benefits (O'Rourke \& Worzbyt, 1996; Schaefer). The group leader may benefit from some exercises to cope with transference which may arise in group counseling process. Exercises and experiments used in group counseling are verbal or non-verbal practices requested by the leader with the aim of helping to client to recognize him, to deal with transference and to maintain the group process (Voltan-Acar, 2014). Exercises are used both in group counseling and individual counseling with the aim of helping to client. These exercises may be implemented in group process but the leader who would implement the exercises should have sufficient background, ability and experiences. In this regard, he should have a theoretical background as well as practical experiences (Berg \& Landreth, 2013; Luke \& Hackney, 2007; Smith, 2009; Voltan-Acar, 2014).

Exercises should not be used just to break the silence or to show how group counseling is important. Some exercises may be used to cope with transference arose in the process or with the aim of helping to client to recognize him and others. However, exercises should be thought as means to reach to the aim (Voltan-Acar, 2014). Concisely, these exercises may be useful in group counseling process if they would be used in case of need with proper dose. As it is mentioned before, there are specific exercises to be implemented by the group leader when transference has been faced during the process. So after having sufficient corporate training and knowledge based on his own experiences, the leader may use these exercises providing that they would be used in case of need with proper dose.

\section{Using Exercises to cope with Transference and Countertransference}

Exercises are often used in group counseling process (Gullo et al., 2015). The experienced group leader may benefit from specific exercises to cope with transference in group counseling (VoltanAcar, 2014). In this research, the exercises of Empty Chair, completing Unfinished Business and Role Playing which may be used to cope with transference arose in group counseling process, are explained. The main aim is providing the person to notice his feelings and thoughts. In this sense, methods of Role Playing, Empty Chair and Unfinished Business are used in therapy process to reach to this aim (Corey, 2012).

Empty Chair: This exercise is used to provide the client to notice alternative feelings and reactions. This exercise which is a very efficient method has an aim to reveal feelings (Corey, 2015; Hackney \& Cormier, 2008; Nazarzadeh \& Foroutan, 2015). In group counseling process it is important to be aware of the feelings. In this exercises there are two chairs located opposite; one is left empty while the client sits on the other. The client is requested to play a role related to his problem. For example he plays the role of father and talks to himself by thinking that he sits on the opposite chair. Then he animates the exact opposite situation, so the client could complete his unfinished business in this way (Corey, 2015). Gestalt therapists are often use this exercises to cope with transference (Nazarzadeh \& Foroutan, 2015) 
Role Playing: Another exercise used to cope with transference is Role Playing. In this method it is aimed to be aware of feelings and establish balance (Corey, 2015) The Psychodrama model developed by Jacob Moreno and the technique of role playing is still used by many researchers (Corey, 2015; Schaefer, 2011; Smith, 2009). In Role Playing, the group member who would be studied on is placed to the center and other members undertake the roles of important persons or supporting roles in his life. The past of that person would be animated on that time by the way of dramatization. Thanks to this method, that member could express his feelings and face his problems (Vander Kolk, 1985). The techniques of Role Playing are very useful methods in group counseling process. Group members attend much more easily to the therapeutic process when they relive the happenings experienced throughout their life by playing a role on the stage rather than explaining them shortly (Schaefer, 2011). It is also helpful in case a group member has an internal conflict regarding to value judgment, feelings, personality and have a difficulty to comprehend the core of conflict. The aim in this exercise is providing the client to make an evaluation related to his thoughts, feelings and behaviors. Whenever the group member could express his feelings, desired results would have been succeeded without playing a role (Hackney ve Cormier, 2008).

Unfinished Business: Unfinished Business can be defined as an exercise used within the Gestalt therapy. This exercise is related to unvoiced or elusive feelings. According to Corey (2015), if people cannot express their feelings such as resentment, anger, sorrow, guiltiness and live them in their inner world, these turn to be unfinished business. As the person would involuntarily be under the effect of these feelings, they cause to a constant unrest and are transferred to his daily life in a way of preventing to establish efficient relations with others. In group counseling process group leader have to work unfinished business because if group members want to became free they have to resolve unfinished business (Gültekin \& Voltan-Acar, 2004).

As a result, unvoiced feelings lead to tension in person's inner world. These unexpressed feelings emerged upon his experiences or facts affect his relations within social environment afterwards. In group counseling, the group leader helps to group members to share these experiences and feelings within the group and complete their unfinished business. When client/group member became aware of their feelings the transference could be resolved.

\section{Conclusions and Suggestions}

Group counseling undertakes a preventive and improving method which has a purpose of helping the person (Berg \& Landreth, 2013; Corey, 2012). As individual problems and social problems have increased today, getting a psychological support as a preventing service gains more importance (Capuzzi \& Gross, 2014; Nazl1, 2014). As the group forms a small component of society, transfer of information acquired within the group to real life would be much easier (Voltan-Acar, 2014). However the group leader should deal with transference and countertransference arose in group counseling process (Fehr, 2014). Much more transference may come up in group counseling rather than individual counseling as there would be more transference object due to the number of persons who have been communicated with. Transference within the group should be solved to keep the operation and provide the maintenance of the group (Voltan-Acar, 2014).

In this article some exercises implemented to cope with transference in the light of related literature were explained and the ways to benefit from these exercises were discussed. However it should not be forgotten that these exercises are a means. According to Voltan-Acar (2014), these exercises may be used during the group counseling process, but they should be seen as means to reach the aim. In other words, these exercises benefited during the group counseling process are helpful methods providing transference to be solved, group members to experience new feelings 
and complete the unfinished business in case they would be used at the right time with proper dose.

Besides the current methods taken place in literature to cope with transference in the group counseling process, the method of co-leadership may also be referred to deal with transference and countertransference (Smith, 2009). For example, Moreno has used this method in psychodrama practices to describe transference and countertransference. It is generally accepted that this method is useful. Thanks to the method of co-leadership, an objective perspective may be provided in determination of transference in the group counseling process and a progress within the group may be succeeded (Luke ve Hackney, 2007).

Exercises such as Empty chair, Role playing and completing Unfinished Business explained in this article have a common ground that a person may experience the feelings having not been explained before in the group and express them easily in a group atmosphere (Corey, 2015; Voltan-Acar, 2014). Educational background of psychological counselor who would implement these practices is quite important in terms of the implementation of exercises properly in group counseling and achievement of the goal. There are also some articles in today's literature laying emphasis on psychological counselor's education (Smith, 2009; Southern, 2007). As a result, this kind of exercises may be benefited in group counseling to cope with transference after having attended to essential trainings and practices.

\section{References}

Battle, K. (2016). Grief \& At-Risk Behavior: A look at the effectiveness of grief counseling groups for adolescents in public schools. National Youth-At-Risk. Conference Savannah. Paper 192.

Beelmann, A., \& Heinemann, K. S. (2014). Preventing prejudice and improving intergroup attitudes: A meta-analysis of child and adolescent training programs. Journal of Applied Developmental Psychology, 35(1), 10-24.

Berg, R. C., \& Landreth, G. L. (2013). Group Counseling: Concepts and Procedures Fourth Edition. Routledge.

Capuzzi, D., \& Gross, D. R. (2014). Youth at risk: a prevention resource for counselors, teachers, and parents. New Jersey: John Wiley \& Sons.

Clarkson, P., \& Nuttall, J. (2000). Working with countertransference. Psychodynamic Counseling, 6(3), 359-379.

Conyne, R. K. (2013). Türk psikolojik danışma eğitimi programlarına önleyici anlayışı dâhil etmek: yeterlikler ve stratejiler. Türk Psikolojïk Danışma ve Rehberlik Dergisi, 4(39), 1-12.

Corey, G. (2015). Theory and practice of counseling and psychotherapy. Nelson Education.

Corey, G. (2012). Theory \& practice of group counseling (8th Ed.). CA: Brooks/Cole.

Duck, S. (2007). Human relationships. (4th. Edition). London: SAGE Publications.

Fehr, S. S. (2014). Introduction to group therapy: A practical guide. Routledge.

Freud, S. (1912). The dynamics of transference. Essential papers on transference analysis, 5-17.

Goldblatt, M. J., Briggs, S., \& Lindner, R. (2015). Destructive groups: The role of projective identification in suicidal groups of young people. British Journal of Psychotherapy, 31(1), 3853.

Gullo, S., Coco, G. L., Di Fratello, C., Giannone, F., Mannino, G., \& Burlingame, G. (2015). Group climate, cohesion and curative climate. A study on the common factors in group 
process and their relation with members attachment dimensions. Research in Psychotherapy: Psychopathology, Process and Outcome, 18(1).

Gültekin, F., \& Acar, N. V. (2004). Transaksiyonel analizin Türk kültürüne uygulanabilirliği: kültür açısından eleştirel bakış. Ë̆itim ve Bilim, 29(133).

Hackney, H., \& Cormier, S. (2008). Professional counselor: a process guide to helping (T. Ergene and S. A. Sevim, Trans.). Ankara: Mentis Yayıncilik.

Luke, M., \& Hackney, H. (2007). Group coleadership: a critical review. Counselor Education and Supervision, 46(4), 280-293.

Marmarosh, C. L. (2012). Empirically supported perspectives on transference. Psychotherapy, 49(3), 364.

Nazarzadeh, F. \& Foroutan, S. (2015). The effectiveness of Gestalt therapy and Cognitive therapy to improve the quality of life of patients with hypertension. Journal of Novel Applied Sciences, 4 (9). 919-922.

Nazlı, S. (2014). Kapsamle gelişimsel rehberlike programı. (5. Baskı). Ankara: Anı Yayıncılık.

O'Rourke, K. \& Worzbyt, J. C. (1996). Support groups for children. Philadelphia: Taylor \& Francis Ltd.

Schaefer, C. E. (Ed.). (2011). Foundations of play therapy. John Wiley \& Sons.

Smith, A. L. (2009). Role play in counselor education and supervision: Innovative ideas, gaps, and future directions. Journal of Creativity in Mental Health, 4(2), 124-138.

Southern, S. (2007). Countertransference and intersubjectivity: Golden opportunities in clinical supervision. Sexual Addiction \& Compulsivity, 14(4), 279-302.

Ulberg, R., Hersoug, A. G., \& Høglend, P. (2012). Treatment of adolescents with depression: the effect of transference interventions in a randomized controlled study of dynamic psychotherapy. Trials, 13(1), 159.

Vander Kolk, C. (1985). Introduction to group counseling and psychotherapy. Columbus: Charles E. Merril Publishing Company.

Voltan-Acar, N. (2014). Grupla psikolojik danısma ilke ve teknikleri. (10. Basker). Ankara: Nobel Yayincilik. 